Original Article

\title{
STABILITY INDICATING RP-HPLC METHOD DEVELOPMENT AND VALIDATION FOR THE SIMULTANEOUS DETERMINATION OF VILDAGLIPTIN AND METFORMIN IN PHARMACEUTICAL DOSAGE FORM
}

\author{
RAMESH JAYAPRAKASH*, SENTHIL KUMAR NATESAN \\ Department of Pharmaceutical Analysis, JKK Munirajah Medical Research Foundation's-Annai JKK Sampoorani Ammal College of \\ Pharmacy, Komarapalayam, Namakkal-DT, Tamilnadu, India \\ Email: rameshj1974@gmail.com
}

Received: 19 Nov 2016 Revised and Accepted: 17 Jan 2017

\section{ABSTRACT}

Objective: The present study was aimed to develop a rapid, accurate, linear, sensitive and validate stability-indicating high performance liquid chromatographic [RP-HPLC] method for determination of vildagliptin and metformin in pharmaceutical dosage form.

Methods: The chromatographic separation was performed on kromasil-C 18 column [4.5 x $250 \mathrm{~mm}$; 5 m] using a mobile phase consisting of 0.05 mmol potassium dihydrogen phosphate buffer: acetonitrile [80:20 v/v], [pH adjusted to 3.5 using orthophosphoric acid]. The flow rate is 0.9 $\mathrm{ml} / \mathrm{min}$ and the detection was carried out at $263 \mathrm{~nm}$.

Results: The chromatographic condition, the peak retention time of metformin and vildagliptin were found to be 2.215 min and 2.600 min respectively. Stress testing was performed in accordance with an international conference on harmonization [ICH] Q1A R2 guidelines. The method was validated as per ICH Q2 R1 guidelines. The calibration curve was found to be linear in the concentration range of 5-17.5 $\mu \mathrm{g} / \mathrm{ml}$ and $50-175$ $\mu \mathrm{g} / \mathrm{ml}$ for vildagliptin and metformin. The limit of detection and quantification was found to be $0.0182 \mu \mathrm{g} / \mathrm{ml}$ and $0.0553 \mu \mathrm{g} / \mathrm{ml}$ for vildagliptin and $0.4451 \mu \mathrm{g} / \mathrm{ml}$ and $1.3490 \mu \mathrm{g} / \mathrm{ml}$ for metformin respectively.

Conclusion: A new sensitive, simple and stability indicating reverse-phase high-performance liquid chromatography [RP-HPLC] method has been developed and validated for the determination of vildagliptin and metformin. The proposed method can be used for routine determination of vildagliptin and metformin.

Keywords: Metformin, Method validation, RP-HPLC, Stability indicating method, Vildagliptin

(C) 2016 The Authors. Published by Innovare Academic Sciences Pvt Ltd. This is an open access article under the CC BY license (http://creativecommons.org/licenses/by/4.0/) DOI: http://dx.doi.org/10.22159/ijpps.2017v9i3.16233

\section{INTRODUCTION}

Vildagliptin [fig. 1] is chemically [S]-1-[N-[3-hydroxy-1-adamantyl] glycyl] pyrrolidine-2-carbonitrile, is a potent di-peptidyl peptidase IV [dip-IV] inhibitor, a drug for the treatment of diabetes. DPP-IV inhibitor represents a new class of oral antihyperglycemic agents to treat patients with type 2 diabetes [1-4].

Metformin $\mathrm{HCl}$ [fig. 2] chemically 3-[diaminomethylidene]-1,1dimethylguanidine $\mathrm{HCl}$ is an orally administered biguanide widely used in the treatment of type 2 [non-insulin dependent] diabetes mellitus [5-6].

Literature survey revealed that RP-HPLC [7-16] have been reported for the estimation of vildagliptin and metformin.

To the best of our knowledge, no stability indicating reversephase high-performance liquid chromatography [RP-HPLC] method has been reported for vildagliptin and metformin. The present work involves stress degradation as per ICH Q1A [R2] and Q1B [17-18] for the developing new, simple, sensitive stability indicating RP-HPLC method; the method was validated as per the ICH guidelines Q2 R1 [19].

The reported methods were not cost effective due to use costly solvents and in some methods the retention time vildagliptin was found to be more [7-16]. So in the present work a simple, precise, sensitive and stability indicating method was developed by using low-cost solvent acetonitrile with buffer in the ratio of 80:20, detected by using a photodiode array detector which was highly sensitive to detect at a lower concentration. The developed method was used for estimation of vildagliptin and metformin in pharmaceutical dosage form

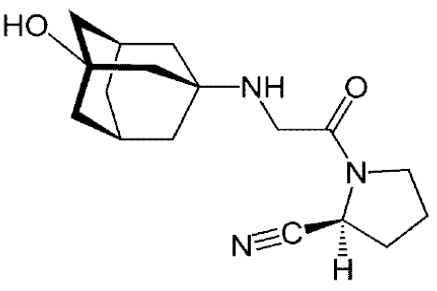

Fig. 1: Chemical structure of vildagliptin<smiles>CN(C)C(=N)NC(=N)N</smiles>

Fig. 2: Chemical structure of metformin Hcl

\section{MATERIALS AND METHODS}

\section{Chemicals and reagents}

Vildagliptin was provided as a gift sample by Aurobindo pharmaceuticals limited [Hyderabad, India]. Metformin $\mathrm{HCl}$ was provided as a gift sample by Ranbaxy laboratories limited [Gurgaon, India]. Acetonitrile [HPLC grade] purchased from E-Merck specialities private. Limited [Mumbai, India], and Potassium 
dihydrogen phosphate $\left[\mathrm{KH}_{2} \mathrm{PO}_{4}\right]$ purchased from Qualigens fine chemicals limited [Mumbai, India].

\section{Instruments}

Chromatography was performed on Waters HPLC 2695 equipped with quaternary pumps with PDA detector. The chromatographic separation was performed using kromasil- $\mathrm{C}_{18}$ column [4.5 x 250 $m m \times 5 \mu m$ particle sizes]. Data acquisition and integration were performed using empower 2 software.

\section{Methods}

\section{Chromatographic conditions}

The method development for analysis of vildagliptin and metformin Hcl was performed using various solvents finally the separation was achieved using a mobile phase consisting of $0.05 \mathrm{mmol}$ potassium dihydrogen phosphate buffer: acetonitrile [80:20 v/v], pH adjusted to 3.5 using orthophosphoric acid, pumped at a flow rate of 0.9 $\mathrm{ml} / \mathrm{min}$. The eluent was monitored using a PDA detector at a wavelength of $263 \mathrm{~nm}$. The mobile phase was vacuum filtered through $0.22 \mu \mathrm{m}$ nylon membrane filter followed by degassing in an ultrasonic bath prior to use.

\section{Preparation of solutions}

\section{Preparation of buffer solution}

The buffer solution was prepared by dissolving $0.68 \mathrm{~g}$ of potassium dihydrogen orthophosphate in $1000 \mathrm{ml}$ of water, and the $\mathrm{pH}$ was adjusted to 3.5 by adding orthophosphoric acid dropwise.

\section{Preparation of standard solutions}

The quantity of powder equivalent to $50 \mathrm{mg}$ of vildagliptin and 500 $\mathrm{mg}$ of metformin were weighed and transferred into a $100 \mathrm{ml}$ volumetric flask, $30 \mathrm{ml}$ of diluent was added and sonicated for 15 min and the volume was made up to the mark with diluent. From this solution, further dilution was made to get the final concentration of $12.5 \mu \mathrm{g} / \mathrm{ml}$ and $125 \mu \mathrm{g} / \mathrm{ml}$ of vildagliptin and metformin respectively.

\section{Validation of the developed method}

The optimized analytical method was validated for system suitability, linearity and range, precision, limit of detection [LOD], limit of quantitation [LOQ] and accuracy in accordance with ICH guidelines for analytical procedures Q2[R1].

\section{System suitability}

System suitability parameters were studied to verify the system performance. Six replicate samples containing vildagliptin [12.5 $\mu \mathrm{g} / \mathrm{ml}]$ and metformin $[125 \mu \mathrm{g} / \mathrm{ml}]$ were analyzed using the developed method. Factors such as theoretical plate count, tailing factor, percent relative standard deviation [\%RSD] of peak area and retention time were taken into consideration for testing system suitability.

\section{Linearity and range}

The linearity was evaluated at six concentration levels in the range between 5-17.5 $\mu \mathrm{g} / \mathrm{ml}$ for vildagliptin and $50-175 \mu \mathrm{g} / \mathrm{ml}$ for metformin. A calibration curve was plotted by plotting concentration against corresponding peak area and linearity was determined using least square regression analysis. The analytical range was established by the highest and lowest concentrations of analyte were acceptable linearity obtained.

\section{Precision}

The precision of the developed analytical method carried out for same concentration level; six determinations were performed, both intra-day and inter-day variation were expressed in term of percent relative standard deviation [\% RSD].

\section{LOD and LOQ}

Limit of detection and quantification of the developed method were calculated from the standard deviation of the y-intercepts and slope of the calibration curve of vildagliptin and metformin using the following formula:

$$
\text { Limit of detection }=3.3 \alpha / \mathrm{S}
$$

Limit of quantitation $=10 \alpha / \mathrm{S}$

Where $\alpha$ is the standard deviation of the $y$-intercepts and $S$ is the slope of the calibration curve.

\section{Accuracy}

The accuracy of the developed analytical method was determined by calculating recovery of the analyte of interest. A fixed amount of preanalyzed sample was taken and the standard drug was added at $80 \%, 100 \%$ and $120 \%$ levels. The standard concentration was fixed as $12.5 \mu \mathrm{g} / \mathrm{ml}$ of vildagliptin and $125 \mu \mathrm{g} / \mathrm{ml}$ of metformin, and three concentration levels of $10 \mu \mathrm{g} / \mathrm{ml}, 12.5 \mu \mathrm{g} / \mathrm{ml}$ and $15 \mu \mathrm{g} / \mathrm{ml}$ for vildagliptin and $100 \mu \mathrm{g} / \mathrm{ml}, 125 \mu \mathrm{g} / \mathrm{ml}$ and $150 \mu \mathrm{g} / \mathrm{ml}$ for metformin were added to the standard concentration. Each level was repeated three times. The percentage recovery and percentage relative standard deviation [ $\%$ RSD] were taken into consideration for testing accuracy.

\section{Application of validated method for assay of vildagliptin and metformin in pharmaceutical dosage form}

Tablet powder equivalent to $50 \mathrm{mg}$ of vildagliptin and $500 \mathrm{mg}$ of metformin were weighed and transferred into a $100 \mathrm{ml}$ volumetric flask, $30 \mathrm{ml}$ of diluent was added and sonicated for $15 \mathrm{~min}$ and the volume was made up to the mark with diluent. From this solution further dilution was made to get the final concentration of 12.5 $\mu \mathrm{g} / \mathrm{ml}$ of vildagliptin and $125 \mu \mathrm{g} / \mathrm{ml}$ of metformin, ten microliters of final solutions were injected into the HPLC system; chromatograms were recorded and from the peak areas of vildagliptin and metformin, the amount of drug present in sample was computed.

\section{Forced degradation study}

\section{Acid hydrolysis}

\section{Optimization trial}

Initially, trials were conducted by exposing the sample solution to $0.1 \mathrm{~N}$ hydrochloric acid for $8 \mathrm{~h}$ followed by $1 \mathrm{~N}$ hydrochloric acid for $12 \mathrm{~h}$ and no degradation was observed.

\section{Optimized trial}

A quantity tablet powder equivalent to $50 \mathrm{mg}$ of vildagliptin and 500 $\mathrm{mg}$ of metformin was accurately weighed and transferred to $100 \mathrm{ml}$ volumetric flask and it is dissolved in $30 \mathrm{ml}$ of the diluent. The solution was sonicated for a few minutes to dissolve the drug completely. Then it is filtered through $0.45 \mu$ filter and the volume was made up to $100 \mathrm{ml}$ with diluent. Further pipette $1 \mathrm{ml}$ of the above stock solution and transferred to $10 \mathrm{ml}$ volumetric flask and made up to $10 \mathrm{ml}$ with diluent, from the above solution pipette 2.5 $\mathrm{ml}$ and transferred to $10 \mathrm{ml}$ volumetric flask to that $2.5 \mathrm{ml}$ of $2 \mathrm{~N}$ hydrochloric acid was added and it was diluted to get the final concentration of $12.5 \mu \mathrm{g} / \mathrm{ml}$ of vildagliptin and $125 \mu \mathrm{g} / \mathrm{ml}$ of metformin and refluxed for $30 \mathrm{~min}$ at $80{ }^{\circ} \mathrm{C}, 10 \mu \mathrm{l}$ of the refluxed solutions were injected into the system, and the chromatograms were recorded.

\section{Alkaline hydrolysis \\ Optimization trial}

Initially, trials were conducted by exposing the sample solution to $0.1 \mathrm{~N}$ sodium hydroxide for $8 \mathrm{~h}$ followed by $1 \mathrm{~N}$ sodium hydroxide for $12 \mathrm{~h}$ and no degradation was observed.

\section{Optimized trial}

A quantity tablet powder equivalent to $50 \mathrm{mg}$ of vildagliptin and 500 mg of metformin was accurately weighed and transferred to a 100 $\mathrm{ml}$ volumetric flask and it is dissolved in $30 \mathrm{ml}$ of the diluent. The solution was sonicated for a few minutes to dissolve the drug completely. Then it is filtered through $0.45 \mu$ filter and the volume was made up to $100 \mathrm{ml}$ with diluent. Further pipette $1 \mathrm{ml}$ of the 
above stock solution and transferred to $10 \mathrm{ml}$ volumetric flask and made up to $10 \mathrm{ml}$ with diluent, from the above solution pipette 2.5 $\mathrm{ml}$ and transferred to $10 \mathrm{ml}$ volumetric flask to that $2.5 \mathrm{ml}$ of $2 \mathrm{~N}$ sodium hydroxide was added and it was diluted to get the final concentration of $12.5 \mu \mathrm{g} / \mathrm{ml}$ of vildagliptin and $125 \mu \mathrm{g} / \mathrm{ml}$ of metformin and refluxed for $30 \mathrm{~min}$ at $80^{\circ} \mathrm{C}, 10 \mu \mathrm{l}$ of the refluxed solutions were injected into the system and the chromatograms were recorded.

\section{Degradation under neutral condition}

A quantity tablet powder equivalent to $50 \mathrm{mg}$ of vildagliptin and 500 mg of metformin was accurately weighed and transferred to a 100 $\mathrm{ml}$ volumetric flask and it is dissolved in $30 \mathrm{ml}$ of the diluent. The solution was sonicated for a few minutes to dissolve the drug completely. Then it is filtered through $0.45 \mu$ filter and the volume was made up to $100 \mathrm{ml}$ with diluent.

Further pipette $1 \mathrm{ml}$ of the above stock solution and transferred to $10 \mathrm{ml}$ volumetric flask and made up to $10 \mathrm{ml}$ with diluent, from the above solution pipette $2.5 \mathrm{ml}$ and transferred to $10 \mathrm{ml}$ volumetric flask and made up to $10 \mathrm{ml}$ with diluent to get the final concentration of $12.5 \mu \mathrm{g} / \mathrm{ml}$ of vildagliptin and $125 \mu \mathrm{g} / \mathrm{ml}$ of metformin and the solution was refluxed in water bath for $30 \mathrm{~min}$ at $80{ }^{\circ} \mathrm{C}$ and $10 \mu \mathrm{l}$ of the refluxed solutions were injected into the system and the chromatograms were recorded.

\section{Degradation under oxidative condition}

A quantity tablet powder equivalent to $50 \mathrm{mg}$ of vildagliptin and 500 mg of metformin was accurately weighed and transferred to a 100 $\mathrm{ml}$ volumetric flask and it is dissolved in $30 \mathrm{ml}$ of the diluent. The solution was sonicated for a few minutes to dissolve the drug completely. Then it is filtered through $0.45 \mu$ filter and the volume was made up to $100 \mathrm{ml}$ with diluent.

Further pipette $1 \mathrm{ml}$ of the above stock solution and transferred to $10 \mathrm{ml}$ volumetric flask and made up to $10 \mathrm{ml}$ with diluent, from the above solution pipette $2.5 \mathrm{ml}$ and transferred to $10 \mathrm{ml}$ volumetric flask to that $2.5 \mathrm{ml}$ of $3 \%$ hydrogen peroxide $\left[\mathrm{H}_{2} \mathrm{O}_{2}\right]$ was added and it was diluted to get the final concentration of $12.5 \mu \mathrm{g} / \mathrm{ml}$ of vildagliptin and $125 \mu \mathrm{g} / \mathrm{ml}$ of metformin and refluxed for $30 \mathrm{~min}$ at $80{ }^{\circ} \mathrm{C}, 10 \mu \mathrm{l}$ of the refluxed solutions were injected into the system and the chromatograms were recorded.

\section{Degradation under wet heat condition}

A quantity tablet powder equivalent to $50 \mathrm{mg}$ of vildagliptin and 500 mg of metformin was accurately weighed and transferred to a 100 $\mathrm{ml}$ volumetric flask and it is dissolved in $30 \mathrm{ml}$ of the diluent. The solution was sonicated for a few minutes to dissolve the drug completely. Then it is filtered through $0.45 \mu$ filter and the volume was made up to $100 \mathrm{ml}$ with diluent. Further pipette $1 \mathrm{ml}$ of the above stock solution and transferred to $10 \mathrm{ml}$ volumetric flask and made up to $10 \mathrm{ml}$ with diluent, from the above solution pipette 2.5 $\mathrm{ml}$ and transferred to $10 \mathrm{ml}$ volumetric flask and made up to $10 \mathrm{ml}$ with diluent to get the final concentration of $12.5 \mu \mathrm{g} / \mathrm{ml}$ of vildagliptin and $125 \mu \mathrm{g} / \mathrm{ml}$ of metformin and the solution was placed in oven at $80{ }^{\circ} \mathrm{C}$ for $48 \mathrm{~h}, 10 \mu \mathrm{l}$ of the solutions were injected into the system and the chromatograms were recorded.

\section{Photo-degradation studies}

A quantity tablet powder equivalent to $50 \mathrm{mg}$ of vildagliptin and 500 mg of metformin was accurately weighed and transferred to a 100 $\mathrm{ml}$ volumetric flask and it is dissolved in $30 \mathrm{ml}$ of the diluent. The solution was sonicated for a few minutes to dissolve the drug completely. Then it is filtered through $0.45 \mu$ filter and the volume was made up to $100 \mathrm{ml}$ with diluent. Further pipette $1 \mathrm{ml}$ of the above stock solution and transferred to $10 \mathrm{ml}$ volumetric flask and made up to $10 \mathrm{ml}$ with diluent, from the above solution pipette 2.5 $\mathrm{ml}$ and transferred to $10 \mathrm{ml}$ volumetric flask and made up to $10 \mathrm{ml}$ with diluent to get the final concentration of $12.5 \mu \mathrm{g} / \mathrm{ml}$ of vildagliptin and $125 \mu \mathrm{g} / \mathrm{ml}$ of metformin and the solution was exposed to UV light by keeping the volumetric flask in UV chamber for $7 \mathrm{~d}, 10 \mu \mathrm{l}$ of the solutions were injected into the system and the chromatograms were recorded.

\section{RESULTS AND DISCUSSION}

\section{Method development}

\section{Optimization of mobile phase}

Method development for vildagliptin and metformin was started with a different combination of solvents with different ratios. We have tried various buffer-solvent ratios [50:50, 60:40, 70:30, 80:20, and 90:10]. However, finally a combination of $0.05 \mathrm{mmol}$ potassium dihydrogen phosphate buffer $[\mathrm{pH}$ adjusted to 3.5 using orthophosphoric acid]: acetonitrile $80: 20 \mathrm{v} / \mathrm{v}$ has shown good resolution for vildagliptin and metformin. Initially, $1.0 \mathrm{ml} / \mathrm{min}$ flow rate was tried it has not shown adequate separation between vildagliptin and metformin, but further increase and decrease in the flow rate $0.9 \mathrm{ml} / \mathrm{min}$ shows good resolution between the peaks of vildagliptin and metformin. Some reported methods use costly solvents and were found to be less sensitive [7-9]. So the present work was developed by using a low-cost solvent buffer with acetonitrile in ratio 80:20.

\section{Chromatographic conditions}

The analytical conditions were selected, keeping in mind the chemical nature of vildagliptin and metformin. The development trails were taken using different conditions. The column selection has been done on the basis of back pressure, peak shape, theoretical plates and day-to-day reproducibility of the retention time. After evaluating all these factors, the chromatographic separation was carried out on kromasil- $\mathrm{C}_{18}$ column [4.5 x $250 \mathrm{~mm}$; $5 \mu \mathrm{m}$ ] using a mobile phase consisting of $0.05 \mathrm{mmol}$ potassium dihydrogen phosphate buffer [pH adjusted to 3.5 using orthophosphoric acid]: acetonitrile $[80: 20 \mathrm{v} / \mathrm{v}]$, the flow rate $0.9 \mathrm{ml} / \mathrm{min}$ and the injection volume was $10 \mu \mathrm{l}$, the detection was carried out at $263 \mathrm{~nm}$.

The peak retention time of metformin and vildagliptin were found to be $2.215 \mathrm{~min}$ and $2.600 \mathrm{~min}$ respectively. The retention times in all the reported methods were more when compared to the developed method [10-14]. Hence this method was finalised as an optimized method for the estimation of vildagliptin and metformin. The optimised chromatographic condition was shown in table 1 and the typical HPLC chromatogram of standard and sample were shown in fig. 1 and 2 .

Table 1: Optimised chromatographic condition for the estimation of vildagliptin and metformin

\begin{tabular}{ll}
\hline Parameter & Condition \\
\hline Mobile phase & $0.05 \mathrm{mmol}$ potassium dihydrogen phosphate buffer: acetonitrile [80:20 v/v], [pH adjusted to 3.5 using \\
& orthophosphoric acid] \\
Diluent & Mobile phase \\
Column & Kromasil- $\mathrm{C}_{18}$ column $[4.5 \times 250 \mathrm{~mm} ; 5 \mu \mathrm{m}]$ \\
Column temperature & $30{ }^{\circ} \mathrm{C}$ \\
Detection wavelength & $263 \mathrm{~nm}$ \\
Injection volume & $10 \mu \mathrm{l}$ \\
Flow rate & $0.9 \mathrm{ml} / \mathrm{min}$ \\
Runtime & $6 \mathrm{~min}$ \\
\hline
\end{tabular}




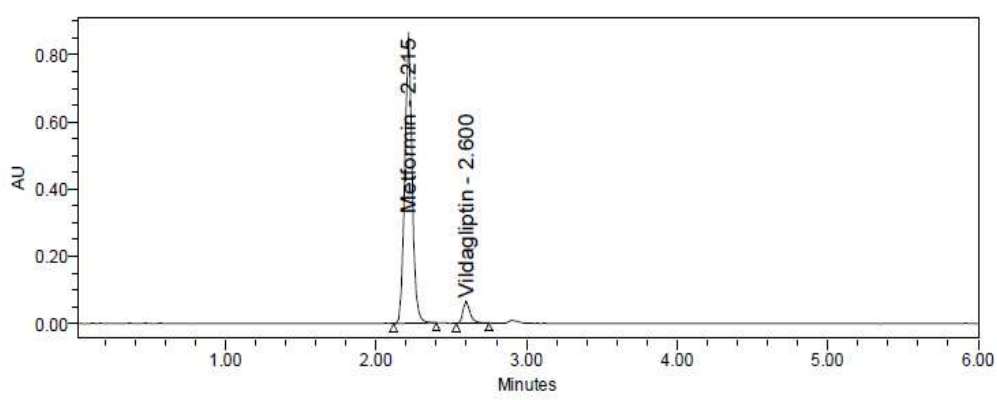

Fig. 1: Typical HPLC chromatogram of standard

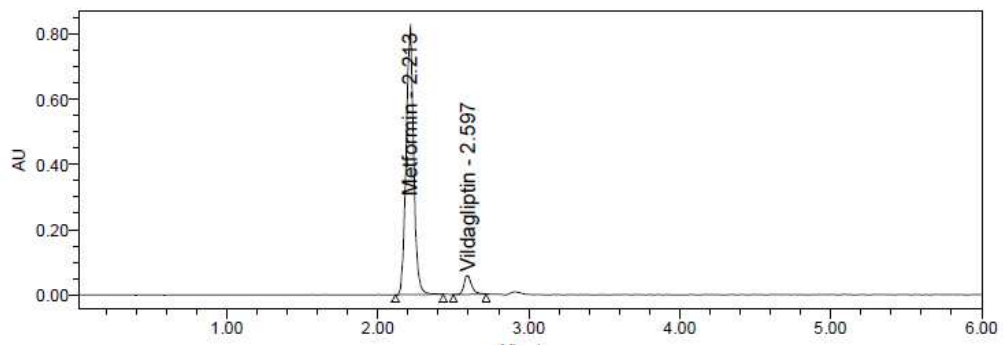

Fig. 2: Typical HPLC chromatogram of sample

\section{Method validation}

\section{System suitability}

The developed method has produced theoretical plate above 2000 for vildagliptin and metformin with tailing factor less than 2 . Similarly, the percent relative standard deviation [\% RSD] of peak area and retention time of vildagliptin and metformin were less than 2 , which ensure the suitability of the developed method. The results of the system suitability study were summarised in table 2 .

\section{Acceptance criteria}

1. The relative standard deviation of six replicate injections for peak area and retention time should not be more than $2.0 \%$.

2. The tailing factor should not be more than 2 .

3. The theoretical plates should not be less than 2000 .

\section{Linearity and range}

For linearity of six point's calibration curve were obtained in concentration ranges from $5-17.5 \mu \mathrm{g} / \mathrm{ml}$ for vildagliptin and $50-175$ $\mu \mathrm{g} / \mathrm{ml}$ for metformin. The response of the drug was found to be linear in the selected concentration range the correlation coefficient for vildagliptin and metformin were 0.9935 and 0.9933 respectively.

The results of linearity of vildagliptin and metformin were summarised in table 3 .

\section{Precision}

The developed method has shown percent relative standard deviation [\% RSD] less than 2 for both intra-day and inter-day precision study, which ensures precision of the developed method. The results of the precision study were summarised in table 4 and 5 .

Table 2: System suitability of the developed method

\begin{tabular}{llll}
\hline Parameters & Name of drug & Acceptance criteria \\
\cline { 2 - 3 } & Vildagliptin & Metformin & \\
\hline Retention time & 2.600 min & 2.215 min & --- \\
Theoretical plates $[\mathrm{N}]$ & 7679 & 9373 & $>2000$ \\
Tailing factor & 1.26 & 1.06 & $<2$ \\
Asymmetry factor & 1.68 & 1.68 & $<2$ \\
Capacity factor & 1.14 & 2.01 & $>1<10$ \\
Resolution & 2.58 & & $>2$ \\
\% RSD of Peak area & 0.1305 & 0.2023 & $<2$ \\
\% RSD of Retention time & 0.7206 & 0.2435 & $<2$ \\
\hline
\end{tabular}

Table 3: Linearity and range of the developed method

\begin{tabular}{lllll}
\hline S. No. & Vildagliptin & & Metformin & Mean peak area $(\mathbf{n}=\mathbf{6})$ \\
\cline { 2 - 5 } & Concentration $(\boldsymbol{\mu g} / \mathbf{m l})$ & Mean peak area $(\mathbf{n}=\mathbf{6})$ & Concentration $(\boldsymbol{\mu g} / \mathbf{m l})$ & 765148 \\
\hline 1 & 5 & 51147 & 50 & 1381755 \\
2 & 7.5 & 109332 & 75 & 2055238 \\
3 & 10 & 160394 & 100 & 2818825 \\
4 & 12.5 & 210773 & 125 & 3376178 \\
5 & 15 & 259822 & 150 & 4138245 \\
6 & 17.5 & 306751 & 175 & 24270.89 \\
Slope & 18313.98 & Slope & -263923.11 \\
y-intercept & -19710.41 & y-intercept & 0.9933 \\
\hline
\end{tabular}


Table 4: Intra-day and inter-day precision of the developed method for vildagliptin

\begin{tabular}{|c|c|c|c|c|c|c|}
\hline \multirow[t]{2}{*}{ Parameter } & \multicolumn{3}{|l|}{ Intra-day } & \multirow[t]{2}{*}{ Parameter } & \multicolumn{2}{|l|}{ Inter-day } \\
\hline & Concentration $(\mu \mathrm{g} / \mathrm{ml})$ & Peak area* & $\%$ amount found* & & Peak area* & $\%$ amount found* \\
\hline $0 \mathrm{H}$ & 12.5 & 212897 & 101.00 & Day-I & 212960 & 101.03 \\
\hline $3 \mathrm{H}$ & & 212903 & 101.05 & Day-II & 212928 & 101.01 \\
\hline $6 \mathrm{H}$ & & 213027 & 101.06 & Day-III & 212811 & 100.96 \\
\hline SD & & & 0.2421 & SD & & 0.2349 \\
\hline$\%$ RSD & & & 0.2398 & $\%$ RSD & & 0.2327 \\
\hline
\end{tabular}

* Mean of six determinations

Table 5: Intra-day and inter-day precision of the developed method for metformin

\begin{tabular}{|c|c|c|c|c|c|c|}
\hline \multirow[t]{2}{*}{ Parameter } & \multicolumn{3}{|l|}{ Intra-day } & \multirow[t]{2}{*}{ Parameter } & \multicolumn{2}{|l|}{ Inter-day } \\
\hline & Concentration $(\mu \mathrm{g} / \mathrm{ml})$ & Peak area* & \% Amount found* & & Peak area* & \% Amount found ${ }^{*}$ \\
\hline $0 \mathrm{H}$ & 125 & 2807870 & 99.60 & Day-I & 2824936 & 100.21 \\
\hline $3 \mathrm{H}$ & & 2817655 & 99.95 & Day-II & 2809835 & 99.67 \\
\hline $6 \mathrm{H}$ & & 2813222 & 99.79 & Day-III & 2803669 & 99.45 \\
\hline SD & & & 0.5391 & SD & & 0.5684 \\
\hline$\%$ RSD & & & 0.5403 & $\%$ RSD & & 0.5696 \\
\hline
\end{tabular}

* Mean of six determinations

\section{Limit of detection and limit of quantification}

Limit of detection [LOD] and limit of quantification [LOQ] was estimated from the standard deviation of the y-intercepts and slope of the calibration curve of vildagliptin and metformin. The LOD and LOQ were found to be 0.0182 and $0.0553 \mu \mathrm{g} / \mathrm{ml}$ for vildagliptin and 0.4451 and $1.3490 \mu \mathrm{g} / \mathrm{ml}$ for metformin. This showed that the developed method can detect and quantify at lower concentration was highly sensitive whereas other methods is less sensitive [7-14]

\section{Accuracy}

The percentage recovery of the spiked sample was within $100 \pm 2 \%$ which ensures the accuracy of the developed method. The results of recovery studies were summarised in table 6 and 7 .

\section{Robustness}

As per ICH, the prepared solution was analysed as per the proposed method with a small but deliberate change in chromatographic conditions as listed below table 8 .

- Change in flow rate

- Change in mobile phase composition

- Change in nanometer

- Change in temperature

- Change in $\mathrm{pH}$

Table 6: Accuracy of the developed method for vildagliptin

\begin{tabular}{|c|c|c|c|c|c|c|}
\hline Parameters & $\begin{array}{l}\text { Amount present } \\
(\mu \mathrm{g} / \mathrm{ml})\end{array}$ & $\begin{array}{l}\text { Amount spiked } \\
(\mu \mathrm{g} / \mathrm{ml})\end{array}$ & $\begin{array}{l}\text { Peak } \\
\text { area }\end{array}$ & $\begin{array}{l}\text { Amount found } \\
(\mu \mathrm{g} / \mathrm{ml})\end{array}$ & $\begin{array}{l}\text { Amount recovered } \\
(\mu \mathrm{g} / \mathrm{ml})\end{array}$ & $\begin{array}{l}\text { \% amount } \\
\text { recovered }\end{array}$ \\
\hline \multirow[t]{3}{*}{$80 \%$} & 12.5 & 10 & 379281 & 22.49 & 9.99 & 100.33 \\
\hline & & & 378455 & 22.44 & 9.94 & 99.84 \\
\hline & & & 377832 & 22.40 & 9.90 & 99.47 \\
\hline \multirow[t]{3}{*}{$100 \%$} & 12.5 & 12.5 & 421146 & 24.97 & 12.47 & 99.97 \\
\hline & & & 421538 & 24.99 & 12.49 & 100.15 \\
\hline & & & 421379 & 24.99 & 12.49 & 100.08 \\
\hline \multirow[t]{3}{*}{$120 \%$} & 12.5 & 15 & 464792 & 27.56 & 15.06 & 100.97 \\
\hline & & & 464586 & 27.55 & 15.05 & 100.88 \\
\hline & & & 464353 & 27.53 & 15.03 & 100.79 \\
\hline Average & & & & & & 100.27 \\
\hline SD & & & & & & 0.4831 \\
\hline$\%$ RSD & & & & & & 0.4818 \\
\hline SE & & & & & & 0.1708 \\
\hline CI (Confidenc & Interval 99\%) & & & & & $99.72-100.81$ \\
\hline
\end{tabular}

Table 7: Accuracy of the developed method for metformin

\begin{tabular}{|c|c|c|c|c|c|c|}
\hline Parameters & $\begin{array}{l}\text { Amount Present } \\
(\mu \mathrm{g} / \mathrm{ml})\end{array}$ & $\begin{array}{l}\text { Amount spiked } \\
(\mu \mathrm{g} / \mathrm{ml})\end{array}$ & $\begin{array}{l}\text { Peak } \\
\text { Area }\end{array}$ & $\begin{array}{l}\text { Amount Found } \\
(\mu \mathrm{g} / \mathrm{ml})\end{array}$ & $\begin{array}{l}\text { Amount Recovered } \\
(\mu \mathrm{g} / \mathrm{ml})\end{array}$ & $\begin{array}{l}\text { \% Amount } \\
\text { Recovered }\end{array}$ \\
\hline \multirow[t]{3}{*}{$80 \%$} & 125 & 100 & 5068347 & 224.75 & 99.75 & 99.78 \\
\hline & & & 5065973 & 224.64 & 99.64 & 99.67 \\
\hline & & & 5096352 & 225.99 & 100.99 & 101.02 \\
\hline \multirow[t]{3}{*}{$100 \%$} & 125 & 125 & 5630324 & 249.67 & 124.67 & 99.80 \\
\hline & & & 5629112 & 249.62 & 124.62 & 99.76 \\
\hline & & & 5630984 & 249.70 & 124.70 & 99.82 \\
\hline \multirow[t]{3}{*}{$120 \%$} & 125 & 150 & 6199615 & 274.92 & 149.92 & 100.05 \\
\hline & & & 6195824 & 274.75 & 149.75 & 99.94 \\
\hline & & & 6198142 & 274.85 & 149.85 & 100.02 \\
\hline Average & & & & & & 99.98 \\
\hline & & & & & & 0.3845 \\
\hline$\%$ RSD & & & & & & 0.3846 \\
\hline & & & & & & 0.1360 \\
\hline CI (Confidenc & Interval 99\%) & & & & & 99.54-100.41 \\
\hline
\end{tabular}


Table 8: Robustness of the developed method for vildagliptin and metformin

\begin{tabular}{|c|c|c|c|c|c|c|}
\hline \multirow[t]{2}{*}{ Parameters } & \multicolumn{3}{|c|}{ Vildagliptin } & \multicolumn{3}{|c|}{ Metformin } \\
\hline & R. T & \% Amount found & \% RSD & R. T & \% Amount found & \% RSD \\
\hline Flow minus $(0.7 \mathrm{ml} / \mathrm{min})$ & 2.591 & 99.17 & 0.3103 & 2.200 & 99.58 & 0.5470 \\
\hline Flow plus $(1.1 \mathrm{ml} / \mathrm{min})$ & 2.597 & 99.13 & 0.5143 & 2.209 & 99.53 & 0.5955 \\
\hline $\mathrm{pH}$ minus $(-0.2)$ & 2.579 & 98.99 & 0.3088 & 2.200 & 99.51 & 0.8448 \\
\hline $\mathrm{pH}$ plus $(+0.2)$ & 2.600 & 98.97 & 0.1975 & 2.212 & 99.63 & 0.4982 \\
\hline nm plus (265) & 2.609 & 98.98 & 0.4710 & 2.213 & 99.58 & 0.6701 \\
\hline $\mathrm{nm}$ minus (261) & 2.609 & 99.11 & 0.2459 & 2.215 & 98.94 & 0.4900 \\
\hline Temperature plus $\left(32^{\circ} \mathrm{C}\right)$ & 2.599 & 99.18 & 0.3548 & 2.212 & 99.18 & 0.3780 \\
\hline Temperature minus $\left(28^{\circ} \mathrm{C}\right)$ & 2.560 & 98.87 & 0.4392 & 2.213 & 99.15 & 0.5752 \\
\hline Acetonitrile (25) & 2.564 & 99.20 & 0.4157 & 2.221 & 98.95 & 0.2893 \\
\hline Acetonitrile (15) & 2.567 & 99.02 & 0.3977 & 2.219 & 99.09 & 0.4153 \\
\hline
\end{tabular}

*Mean of six determinations, $\mathrm{R}$. T = retention time

\section{Application of validated method for assay of vildagliptin and metformin in pharmaceutical dosage form}

Developed method was successfully implemented in the assay of vildagliptin and metformin in pharmaceutical dosage form. Assay of vildagliptin was found to be $99.75 \%$ and for metformin $99.80 \%$. The results of the assay were summarised in table 8 .

The method validation results were satisfactory as per ICH Q2R1 guidelines. The peak areas were found to be linear over the concentration range 5-17.5 $\mu \mathrm{g} / \mathrm{ml}$ and $50-175 \mu \mathrm{g} / \mathrm{ml}$ with a correlation coefficient of 0.9935 and 0.9933 for vildagliptin and metformin respectively. Method specificity can be proved using "Peak purity" parameter in empower 2 software of HPLC. The unaffected assay of the drug in the blend confirms the non-interference by any excipient. Intra-day and inter-day precision were less than $2 \%$. Percent recovery in accuracy study was within the limit of 98 to $102 \%$. The results of validation were summarised in table 9 .

Thus, the optimised HPLC method for vildagliptin and metformin is based on the use of the buffer and acetonitrile. The drug was found to be prone to acid and alkali-catalyzed hydrolysis. The degradation products observed under these conditions were well resolved from the drug peak. Thus the developed method is stability indicating.

Table 8: Assay of vildagliptin and metformin in pharmaceutical dosage form

\begin{tabular}{|c|c|c|c|c|c|c|}
\hline \multirow[t]{2}{*}{ Formulation } & \multicolumn{3}{|l|}{ Vildagliptin } & \multicolumn{3}{|l|}{ Metformin } \\
\hline & $\begin{array}{l}\text { Label claim } \\
\text { (mg) }\end{array}$ & $\begin{array}{l}\text { Amount found } \\
\text { (mg) }\end{array}$ & \% Assay & $\begin{array}{l}\text { Label claim } \\
(\mathrm{mg})\end{array}$ & $\begin{array}{l}\text { Amount found } \\
\text { (mg) }\end{array}$ & \% assay \\
\hline Galvusmet (vildagliptin $50 \mathrm{mg}$ and & 50 & 49.82 & 98.78 & 500 & 502.43 & 100.48 \\
\hline metformin Hcl 500 mg) & & 50.17 & 100.39 & & 500.12 & 100.03 \\
\hline & & 49.53 & 99.19 & & 493.22 & 98.65 \\
\hline & & 50.62 & 100.28 & & 502.71 & 100.55 \\
\hline & & 49.47 & 98.82 & & 500.37 & 100.07 \\
\hline & & 50.58 & 101.05 & & 495.19 & 99.03 \\
\hline Average & & & 99.75 & Average & & 99.80 \\
\hline SD & & & 0.8660 & SD & & 0.7148 \\
\hline$\%$ RSD & & & 0.8681 & $\%$ RSD & & 0.7162 \\
\hline SE & & & 0.4104 & SE & & 0.3197 \\
\hline CI (Confidence Interval 99\%) & & & $\begin{array}{l}98.32- \\
101.17\end{array}$ & CI (Confidenc & nterval 99\%) & $\begin{array}{l}98.62- \\
100.97\end{array}$ \\
\hline
\end{tabular}

Table 9: Summery of validation parameters of the developed method

\begin{tabular}{|c|c|c|c|}
\hline S. No. & Validation parameters & Vildagliptin & Metformin \\
\hline 1 & Linearity range & $5-17.5 \mu \mathrm{g} / \mathrm{ml}$ & $50-175 \mu \mathrm{g} / \mathrm{ml}$ \\
\hline \multirow[t]{3}{*}{2} & Precision & & \\
\hline & - Intra-day precision [\%RSD] & 0.2398 & 0.5403 \\
\hline & - Inter-day precision [\%RSD] & 0.2327 & 0.5696 \\
\hline 3 & Accuracy [\% Recovery] & 100.27 & 99.98 \\
\hline 4 & $\mathrm{LOD}[\mu \mathrm{g} / \mathrm{ml}]$ & 0.0182 & 0.4451 \\
\hline 5 & $\mathrm{LOQ}[\mu \mathrm{g} / \mathrm{ml}]$ & 0.0553 & 1.3490 \\
\hline 6 & Specifity & Specific & Specific \\
\hline 7 & Robustness & Robust & Robust \\
\hline
\end{tabular}

\section{Forced degradation studies}

Forced degradation studies were carried under a condition of acid/base/neutral hydrolysis, oxidation, dry heat and photolysis. For each study, samples were prepared. The blank subjected to stress in the same manner for the drug solution, working standard solution of vildagliptin and metformin subjected to stress degradation. Dry heat and photolytic degradation were carried out in a solid state. The concentration of degrading reagent and time of exposure was optimised to degradation within the range of $10 \%$.
During optimisation of degradation conditions, if the higher percentage of degradation was observed, milder conditions were used for the lesser duration of exposure. If percent degradation is high, there are chances of formation of secondary products.

This was carefully avoided. Although percent assay reduced under all conditions; the separate peak for degradation product was observed only under acid and alkali conditions fig 3 and 4 . Summary of stress degradation results is given in table 9 and 10 . 
In order to develop a suitable RP-HPLC method for the estimation of vildagliptin and metformin, different buffer ratios at different flow rate were applied. Some of the reported methods were costly due to the use of expensive solvents and it was replaced by buffer and acetonitrile in this study. The LOD and LOQ were found to be 0.0182 and $0.0553 \mu \mathrm{g} / \mathrm{ml}$ for vildagliptin and 0.4451 and $1.3490 \mu \mathrm{g} / \mathrm{ml}$ for metformin which indicates that the method was sensitive, and can detect and quantify at lower levels of vildagliptin and metformin. Linearity range was from $5-17.5 \mu \mathrm{g} / \mathrm{ml}$ for vildagliptin and 50-175 $\mu \mathrm{g} / \mathrm{ml}$ for metformin. The response of the drug was found to be linear in the selected concentration range the correlation coefficient for vildagliptin and metformin were 0.9935 and 0.9933 respectively which indicates that at this concentration range both were highly linear. Present assay the amount of both the drugs recovered was found to be $99.75 \%$ for vildagliptin and $99.80 \%$ for metformin. The developed RP-HPLC stability indicating assay method was found to be appropriate for the analysis of drug in their pharmaceutical dosage form.

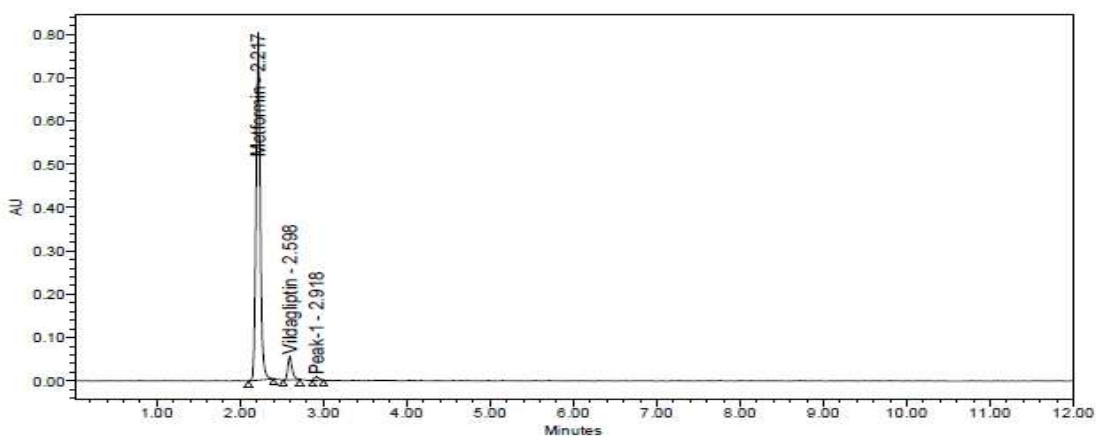

Fig. 3: Chromatogram of acid hydrolysis

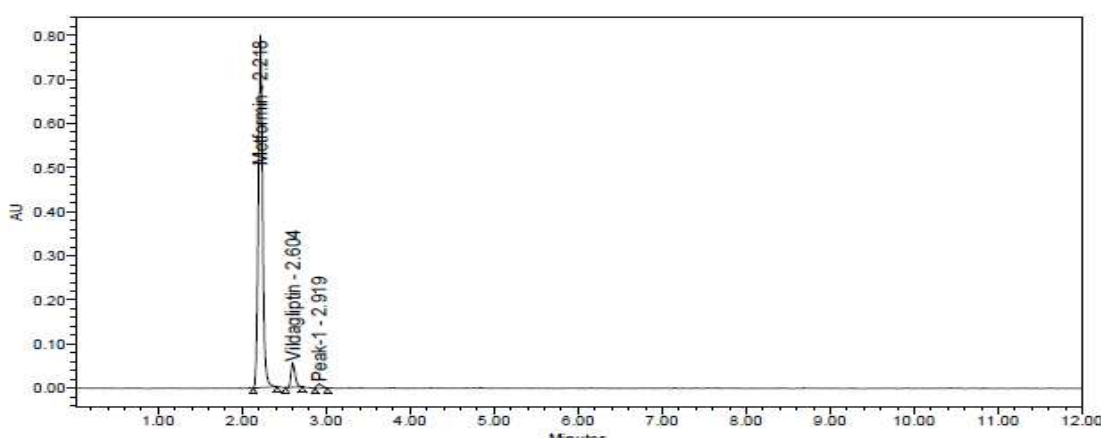

Fig. 4: Chromatogram of alkali hydrolysis

Table 9: Forced degradation study data of vildagliptin

\begin{tabular}{lllll}
\hline Parameters & Degradation time & Peak area* $^{*}$ & \% Degradation & \% of active drug present after degradation \\
\hline Control sample & - & 214581 & - & - \\
Neutral sample & $30 \mathrm{~min}$ & 212693 & 0.89 & 99.98 \\
Acidic degradation & $30 \mathrm{~min}$ & 205634 & 4.21 & 96.66 \\
Alkaline degradation & $30 \mathrm{~min}$ & 207784 & 3.20 & 97.67 \\
Oxidative degradation & $30 \mathrm{~min}$ & 208781 & 2.73 & 98.14 \\
Thermal degradation & $48 \mathrm{~h}$ & 210938 & 1.72 & 99.15 \\
Photolytic degradation & $7 \mathrm{~d}$ & 212693 & 0.95 & 99.92 \\
\hline
\end{tabular}

*Mean of six determinations

Table 10: Forced degradation study data of metformin

\begin{tabular}{lllll}
\hline Parameters & Degradation time & Peak area* & \% degradation & \% of active drug present after degradation \\
\hline Control sample & - & 2832156 & - & - \\
Neutral sample & $30 \mathrm{~min}$ & 2799432 & 1.06 & 99.32 \\
Acidic degradation & $30 \mathrm{~min}$ & 2716181 & 4.12 & 96.36 \\
Alkaline degradation & $30 \mathrm{~min}$ & 2732399 & 3.54 & 96.94 \\
Oxidative degradation & $30 \mathrm{~min}$ & 2777504 & 1.93 & 98.55 \\
Thermal degradation & $48 \mathrm{~h}$ & 2784513 & 1.69 & 98.79 \\
Photolytic degradation & $7 \mathrm{~d}$ & 2799432 & 1.16 & 99.22 \\
\hline
\end{tabular}

*Mean of six determinations

\section{CONCLUSION}

The developed method is stability indicating where wellresolved peaks were observed for analyte and degradation product. The method is specific, accurate, precise, and robust and can be used for routine quality control as well as assessing the stability of vildagliptin and metformin in bulk and in pharmaceutical dosage form. 


\section{ACKNOWLEDGMENT}

The authors wish to express their gratitude to the management of JKKMMRF's-annai JKK sampoorani Ammal College of pharmacy for providing the research facilities, Ranbaxy laboratories limited, Gurgaon, India and Aurobindo pharmaceuticals limited, Hyderabad, India, for providing drug samples.

\section{CONFLICT OF INTERESTS}

Declared none

\section{REFERENCES}

1. McIntosh CH, Demuth HU, Pospisilik JA, Pederson R. Dipeptidyl peptidase IV inhibitors. How do they work as new antidiabetic agents. Regul Pept 2005;128:159-65.

2. Webwr AE. Dipeptidyl peptidase IV inhibitors for the treatment of diabetes. J Med Chem 2004;47:4135-41.

3. Lauster CD, McKaveney TP, Muench SV. Levabuterol: a novel oral therapy for type 2 diabetes mellitus. Am J Health Syst Pharm 2007;64:1265-73.

4. Handan HE, PhiTran, Hequn Yin, Harold Smith, Yannick Batard, Lai Wang, et al. Absorption metabolism and excretion of vildagliptin, a novel dipeptidyl peptidase-4 inhibitor, in humans. Drug Metab Dispos 2009;37:536-44.

5. Cai LI Z, Jian Jie J, Yan Na W, Feng Rui Y, Jun Qui S, Jian Shi L. Study on pharmacokinetics and bioavailability of metformin $\mathrm{Hcl}$ sustained release tablet in healthy chinese volunteers. Asian J Pharmacodynamics Pharmacokinetics 2010;10:221-8.

6. Obaid A, Roohi O, Syed WH. Hypoglycemic potential of tablet metformin $\quad 500 \mathrm{mg}$ (GlucophageandMetaphage): a pharmacological endpoint evaluation. Pak J Pharm Sci 2003; 6:29-41.

7. Mohammed Ishaq B, Vanitha Prakash K, Krishna Mohan G. RPHPLC method for simultaneous estimation of metformin and vildagliptin in bulk and its tablet formulation. J Globle Tren Pharm Sci 2012;3:747-54.

8. Subhakar Nandipati, Krishna Reddy V, Ravindranadh Reddy T. Development and validation of a RP-HPLC method for simultaneous determination of vildagliptin and metformin in bulk and formulation dosage form. Int Res J Pharm Appl Sci 2012;2:44-50.

9. Santhosha B, Ravindranath A, Sundari Ch. Validated method for the simultaneous estimation of metformin hydrochloride and vildagliptin by RP-HPLC in bulk and the pharmaceutical dosage form. Int Res J Pharm Appl Sci 2012;2:22-8.
10. Mohammad Yunoos, Gowri Sankar D. A validated a stabilityindicating high-performance liquid chromatographic method for simultaneous determination of metformin $\mathrm{Hcl}$ and dapagliflozin in bulk drug and tablet dosage form. Asian J Pharm Clin Res 2015;3:320-6.

11. Shrikrishna B Baokar, Sugandha V Mulgund, Nisharani S Ranpise. Development and validation of RP-HPLC method for simultaneous estimation of vildagliptin and metformin. Res J Pharm Dos Forms Technol 2013;5:95-8.

12. PSR CH, NP Varme D, Lakshmana Rao A, Dinda SC. Simultaneous determination of metformin and vildagliptin in solid dosage form by a stability indicating RP-HPLC method. Int Res J Pharm 2013;4:122-8.

13. Gattu Madhava Prathap, Muthukumaran M, Krishnamoorthy B. Development and validation of simultaneous estimation of vildagliptin and metformin hydrochloride by RP-HPLC in bulk and oral dosage form. Int J Adv Pharm Gen Res 2014;2:24-33.

14. Usharani Gundala, Chandra Shekar Bhuvanagiri, Devanna nayakanti. Simultaneous estimation of vildagliptin and metformin hydrochloride in bulk and pharmaceutical dosage form by RP-HPLC. Indo Am J Pharm Res 2013;3:1554-63.

15. Aparajita Malakar, Bishwajit Bokshi, Dilruba Nasrin. Development and validation of a RP-HPLC method for estimation of vildagliptin from tablet dosage form. Int J Pharma Life Sci 2012;1:1-8.

16. Hanumantha Rao K, Lakshmana Rao A, Chandra Sekhar KB. Development and validation of HPLC method for the estimation of vildagliptin in pharmaceutical dosage form. Int J Pharm Chem Biol Sci 2014;4:361-6.

17. International conference on harmonization tripartite guideline on stability testing of new drug substances and products text and methodology: Q1A (R2); 2003.

18. International conference on harmonization tripartite guideline on validation of analytical procedures text and methodology: Q1B; 2005.

19. International conference on harmonization tripartite guideline on validation of analytical procedures text and methodology: Q2 (R1); 2005.

\section{How to cite this article}

- $\quad$ Ramesh Jayaprakash, Senthil Kumar Natesan. Stability indicating RP-HPLC method development and validation for the simultaneous determination of vildagliptin and metformin in pharmaceutical dosage form. Int $\mathrm{J}$ Pharm Pharm Sci 2017;9(3):150-157. 